ARTICLE HISTORY: Received: April 4, 2021 Accepted: May 25, 2021 Published: June 3, 2021

УДК 3(308)

ВКЛАД РУССКОЙ ИНТЕЛЛИГЕНЦИИ В РАЗВИТИЕ УЗБЕКСКОГО ЯЗЫКА

Лукашова Наталья Михайловна кандидат исторических наук, дочент кафедры «Общественнье науки» Наманганского инженерно-технологического института, 2. Наманган, Республика Узбекистан

\title{
CONTRIBUTION OF THE RUSSIAN INTELLIGENCE TO THE DEVELOPMENT OF THE UZBEK LANGUAGE
}

\author{
Lukashova Natalia Mikhailovna \\ Candidate of Historical Sciences, \\ Associate Professor of the Department of Social Sciences \\ Namangan Engineering and Technological Institute, \\ Namangan city, Republic of Uzbekistan
}

\begin{abstract}
Аннотация. В статье на основе архивных и историографических материалов проанализирован вклад в изучение узбекского литературного языка одного из просветителей В. П. Наливкина. В статье отражена также его педагогическая деятельность-подготовка талантливых специалистов.

Abstract. In the article, on the basis of archival and historiographic materials, the contribution to the study of the Uzbek literary language of one of the enlighteners of V.P. Nalivkin is analyzed. The article also reflects his teaching activities - training talented specialists.

Ключевые слова: Ориентализм в Туркестане, учительская семинария, педагогическое просвещение, словарь, диалекты и лингвистика.

Key words: Orientalism in Turkestan, teachers' seminary, pedagogical education, vocabulary, dialects and linguistics.
\end{abstract}

Национальный язык - это историческое явление, система звуковых знаков, являющаяся средством общения, познания и понимания бытие. Именно понимания. А там, где есть понимание, будет и уважение, и интерес друг к другу. Необходимость знания языка того народа, на земле которого живешь, понимали многие из исследователей истории Средней Азии. До конца XIX века в Туркестане практически отсутствовал современный узбекский литературный язык, тем более языковедение как наука. Местные грамотные люди использовали старописьменный язык эпохи феодализма. Живой узбекский язык оставался на обочине культурной жизни общества. Для используемого языка было характерно явное перенасыщение арабской и персидской лексикой.

Практическое и научное изучение живых тюркских языков энергично взяли в свои руки представители, так называемого провинциального ориентализма [2, с.279]. Его самыми яркими фигурами были Н.П.Остроумов, В.П.Наливкин и их ученики Н.С.Лыкошин, В.Ф.Ошанин, Н.Г.Маллицкий и др. Их творческие усилия поддержали крупнейшие востоковеды России, специалисты в области тюркских и иранских языков:академикиК.З.Залеман, В.Р.Розен, В.В.Бартольд, П.М.Мелиоранский. Языки коренного населения Средней Азии стали изучаться местными исследователями, так, как в научной академической среде результатов изучения живого, узбекского языка практически не было. Именно эти исследования в части накопления фактического материала составили базу для дальнейших научных изысканий профессиональных специалистов. Впервые на научную основу было поставлено и изучение узбекского языка. Его преподавали в Туркестанской учительской семинарии, в Ташкентском реальном училище, на курсах восточных языков при Ташкентском отделении Общества Востоковедения.

Настоящее исследование посвящено одному из представителей интеллигенции Туркестана - Владимиру Петровичу Наливкину. Для профессионалов историков и, в особенности, специалистов-этнологов, а также историографов, занимающихся исследованием проблем, касающихся периода конца XIX - начала XX вв. это имя не является неизвестным. Этнограф, историк, преподаватель, лингвист, исследователь истории ислама... не было, кажется такой сферы деятельности, где бы В.П.Наливкин не оставил заметный след. Цель настоящего исследования состоит в необходимости дать взвешенную, объективную, оценку роли его педагогической и научной деятельности в области изучения узбекского и других языков Туркестанского края. 
Условия, в которых проходило знакомство В.П.Наливкина с языками коренного населения Туркестанского края были не совсем обычными. Вместо того, чтобы изучать курс «введения в языкознание» или штудировать грамматику языка, он знакомился с живой разговорной речью. Таким образом, в результате подобных практических занятий, В.П.Наливкин глубоко и всесторонне изучил узбекский, таджикский и другие языки, собрал значительный исследовательский материал (записи сказок, песен, преданий и т.д.), прошёл прекрасную школу, причём самостоятельную, исследователя-лингвиста. Вместе с молодой женой он сначала поселился в двадцати пяти верстах от города Намангана в урочище Радван среди кипчаков, а затем, приобрел небольшой земельный участок в кишлаке Нанай, где стал изучать жизнь и быт коренного населения.

Так началась, по словам Ю.О.Якубовского (отец будущего известного историка А.Ю.Якубовского), «...скромная, но в высшей степени плодотворная, и, можно сказать, беспримерная в истории Туркестана, деятельность супругов Наливкиных по изучению языка, быта, религии и обычаев ферганского туземца, не по книжным источникам, а из самих источников жизни народной... Зимой они жили в Нанае среди узбеков, а летом с киргизами откочевывали в горы. Жизнь была далеко не легкая. В такой обстановке, в сырой холодной сакле, согреваясь одеялом за общим сандалом, родились и воспитывались дети, до семи-восьми лет не знавшие русской речи... (в этот период у Наливкиных было двое детей: сыновья Борис (1876 года рождения) и Владимир (1878 года рождения). Зато результаты получились блестящие. Супруги усвоили узбекский язык в такой тонкости, какая не достигается учебниками и школами. Знанием живой разговорной речи узбекского и таджикского языков В.П. поражал солидных ученых-востоковедов» [3, с.84]. Судя по всему, Наливкиными в такой же степени был освоен и киргизский язык. Владимир Петрович знал также грузинский язык, в совершенстве владел французским. Мария Владимировна Наливкина блестяще владела французским и немецким языками.

Этот период жизни позволил В.П.Наливкину очень близко познакомиться с бытом населения Ферганской долины. За время своих многочисленных путешествий по Наманганскому уезду, о которых мы узнаем из его работ. Он имел возможность непосредственно наблюдать богатую и самобытную культуру узбеков, таджиков и киргизов.

В сотрудничестве с женой М.В.Наливкиной Владимир Петрович предпринял первую попытку научного изучения узбекского языка по говорам Ферганской долины. В начале 80-х годов XIX века вышли в свет их первые лингвистические работы. Среди них «Русско-сартовский и сартовско-русский словарь общеупотребительных слов с приложением краткой грамматики по наречиям Наманганского уезда», опубликованный в Казани в 1884 году.[4]. Соавтором В.П.Наливкина была его жена - Мария Владимировна Наливкина, составившая вторую часть - «Сартовско-русский словарь» / эта часть состояла из 161 страницы Н.Л/. Фактически это был первый опыт диалектологического изучения узбекского языка. В приложении к русско-сартовскому словарю М.В.Наливкиной была составлена «Грамматика сартского языка Андижанского наречия» [5]. Несмотря на несовершенство фонетической транскрипции, предпочтение, отданное книжному языку, материалы словаря Наливкиных, явились единственным источником в области изучения узбекского языка в тот период.

Эти работы Наливкиных внесли весомый вклад в разработку и изучение диалектов узбекского языка. Известные тюркологи К.К.Юдахин и А.Н.Кононов считали, что словарь Наливкиных долгое время оставался лучшим из узбекских словарей, а составленная, для него грамматика - была первым «грамматическим очерком» одного из диалектов узбекского языка [6, с.402]. Более того, А.Н.Кононов справедливо относил этот словарь, к числу отечественных словарей, «...составивших эпоху в истории тюркской лексикографии, не имеющих себе равных в западноевропейской тюркологии» [7, с.6].Такой высокий отзыв из уст маститых ученыхпрофессионалов языкознания - высшая оценка труда исследователей. В этой связи А.К.Боровков отмечал, что словарь Наливкиных был единственным источником по узбекскому языку для составления грандиозного словаря В.В.Радлова [8, с.184]. А архивные материалы зафиксировали информацию о том, что словарь Наливкиных использовался в качестве учебного пособия в таком солидном учебном заведении, как Лазаревский институт восточных языков в Москве [9. л.37,37 об.].

В 1884 году В.П.Наливкин стал первым учителем русско-туземной школы, открытой в Ташкенте. Недостаток финансов, выделяемых для школы, побудили его даже истратить на ее нужды значительную часть личных средств, вырученных от продажи, изданного в 1884 году «Сартовско-русского словаря». Для обучения чтению и письму на русском языке Наливкиным была составлена «Азбука для русско-мусульманских школ оседлого населения Туркестанского края», изданная в 1886 году в количестве 480 экземпляров. Автор старался сделать свой учебник максимально более доступным для детей, которые обучались русскому языку как иностранному. В частности, он считал, что для удобства усвоения русских букв, первая часть азбуки должна быть напечатана письменным шрифтом, т.е. следовало избегать распространенной в России практики смешения письменного и печатного шрифта в одном учебнике, что существенно затруднило бы процесс обучения. [10.л.1 об.].

В.П.Наливкин всячески стремился расширить кругозор обучающихся за счет применения дополнительных учебных пособий. Он использовал в процессе преподавания учебники по истории, географии, употреблявшиеся 
в русских городских училищах. [11, с.270]. Деятельность востоковеда в стенах русско-туземной школы продолжалась до августа 1888 года. С 1885 по 1890 гг. он преподавал узбекский и персидский языки в Туркестанской учительской семинарии. Четырехклассная, мужская учительская семинария была открыта в городе Ташкенте в 1879 году и стала единственной педагогической школой на всей территории Туркестанского края. Это учебное заведение было призвано готовить учителей для русских и русско-туземных школ, а также переводчиков для работы в административном аппарате края. В учебной программе семинарии особое внимание уделялось преподаванию языков коренного населения края. Один из известных исследователей Средней Азии, «патриарх туркестановедения», «лучший знаток ислама в Туркестане» Николай Петрович Остроумов, после назначения его директором Туркестанской учительской семинарии в 1879 году, стал проводить большую работу по изучению живых восточных языков: киргизского (казахского), сартовского (узбекского) и таджикского (персидского). Семинария являлась в тот период единственным в крае профессиональным средним учебным и научным заведением. С помощью преподавателя В.П.Наливкина Остроумовым была создана своеобразная лингвистическая лаборатория при семинарии. Узбекский язык изучали в течение четырех лет. Пособием для обучения служила специально составленная В.П.Наливкиным хрестоматия на узбекском языке [12]. Персидский язык изучался три года, начиная со второго учебного класса. Один из директоров Туркестанской учительской семинарии Ю.Ф. Крачковский отзывался о его преподавании следующим образом: «Присмотревшись близко к занятиям господина Наливкина я нахожу: 1) что этот человек не только хорошо владеет своим предметом, но умеет передать его и даже заинтересовать воспитанников; 2) не останавливаясь на одном каком-нибудь способе обучения, он старается вводить все приемы, которые ведут к скорому и успешному достижению цели; 3) постоянно и в высшей степени аккуратен по службе и исполнителен; 4) кроме классных занятий господин Наливкин ведет с воспитанниками и внеклассные беседы, в которых указывает им те, или другие сочинения для чтения, те или другие средства для скорейшего усвоения предмета и даже предлагает свои личные услуги» [13, л.19]. Подводя итог, Ю.Ф.Крачковский делал вывод, что «..официальный умственный ценз господина Наливкина ниже его действительного умственно-нравственного уровня, так как это человек дела, человек науки» [13]. О преподавательской методике Владимира Петровича вспоминал и известный в будущем туркестановед Н.С.Лыкошин, посещавший первые курсы узбекского языка для офицеров и чиновников в Ташкенте, организованные в 1886 году: «Мы, слушатели, восхищались блестящим, увлекательным изложением интересующего нас предмета. Простое обучение языку сопровождалось и иллюстрировалось беседой о туземных обычаях и декламацией стихов. Слушатели восхищались, ... но платонически» [14, с.84]. В течение двух лет Наливкин обучил 50 офицеров. Для этих курсов им были изданы методические указатели и словари.

Одновременно с педагогической деятельностью во всей широте развернулась его исследовательская работа. По словам известного историографа Узбекистана Б.В.Лунина, в сравнении с В.П.Наливкиным никто из его современников не сделал так много в деле составления различных учебных пособий, словарей, хрестоматий, имевших целью облегчить изучение узбекского и других языков коренного населения Средней Азии [15, с. 254].

Исключительной заслугой В.П.Наливкина явилось составление им высокопрофессиональных учебных пособий, долгое время для очень многих служивших подспорьем в изучении узбекского, персидского и других языков, как при самостоятельном изучении, так и в учебных заведениях. Выше уже говорилось о составлении В.П.Наливкиным «Азбуки...» для русско-туземных школ и хрестоматии для изучения узбекского языка в Туркестанской учительской семинарии [16]. Кроме них им было также составлено «Руководство к практическому изучению сартовского языка», которое была издано в 1899 году в Самарканде и в 1911 году переиздано в Ташкенте. Во вторую часть «Руководства...» вошли два словаря: «Русско - сартовский» и «Сартовско - русский», в каждом из которых было зафиксировано около двух тысяч слов с транскрипцией /подсчитано нами - Н.Л./. Огромный исследовательский интерес специалистов историков, этнологов представляет помещённый в пособии фольклорный материал: пословицы, рассказы, исторические повествования на узбекском языке. В 1912 году ко второму изданию «Руководства...» автором был заново составлен специальный «Русско - сартовский и сартовско - русский словарь», который значительно дополнил сведения об узбекском языке. Обучая русских воспитанников Туркестанской учительской семинарии узбекскому и таджикскому языкам, В.П.Наливкин привел в систему собранные лексические и грамматические материалы и попытался оформить свой курс в методическом отношении, подготовив несколько учебных пособий, тем самым заложив основы этого курса в семинарии. Занимаясь самостоятельно изучением местных языков и этнографией, он пытался привить к ним интерес семинаристов, увлечь их. С этой целью В.П.Наливкин организовал кружок туркестановедения, в которых знакомил учащихся с хорошо известным его бытом узбеков, таджиков, киргизов, с историей Средней Азии. Воспитывая интерес учащихся, к этнографическому прошлому народов Средней Азии, В.П.Наливкин старался привлечь их к самостоятельным научным исследованиям. По его инициативе стала практиковаться отправка воспитанников семинарии на летние каникулы в отдаленные кишлаки с целью сбора этнографических материалов (говоря современным научным языком - сбор полевых материалов) [17, с.128]. Кроме тюркских, востоковед занимался также изучением иранских языков. Им были опубликованы следующие работы: «Сартовско - персидская хрестоматия, с приложением примеров для перевода с русского на сартовский и персидский языки» (1887г.), «Русско-персидский словарь 
общеупотребительных слов по наречиям Туркестанского края» (1889 г.), «Руководство к практическому изучению персидского языка» (1900 г.).

Как исследователя в области языкознания его также интересовали малоизученные языки, относящиеся к восточно-иранской группе. Сохранилась его переписка с академиком К.Г.Залеманом следующего содержания. В одном из писем К.Г.Залеману он сообщал: «На днях же, совершенно случайно я слышал, что в Синтабе / кишлак в верстах 100 от Джизака/ местные жители говорят на каком-то особом наречии, которого совсем не понимают их ближайшие соседи таджики / это совсем новость/. Постараюсь проверить этот слух и сообщить Вам...» $[18$, л.9]. В другом письме он уже писал: «... в конце пасхи еду в Джизак. Проехать в Синтаб мне не удаётся. Поэтому, если я узнаю, что в Синтабе действительно говорят на особом наречии, то я постараюсь достать... двух - трёх синтабцев, запишу все, что успею и пришлю Вам» [18, л.5,5 об.]. В следующем письме речь шла о записях шугнанского языка $[18$, л.7-8]. Свою увлеченность изучением неизвестных языков и диалектов Владимир Петрович передал и своим ученикам.

Благодаря деятельности Владимира Петровича Наливкина, Туркестанская учительская семинария стала первым и продолжительное время единственным центром практического и научного изучения живых узбекского и таджикского языков, их наречий и диалектов. По окончании обучения русские учителя, разбросанные по всему Туркестанскому краю, продолжали заниматься научными исследованиями. Сосредоточение высокоодаренных интеллектуальных кадров преподавателей в Туркестанской учительской семинарии (включая самого Владимира Петровича), занимающихся одновременно научным изучением края, позволили создать уникальную систему образования по подготовке специалистов, имена которых были хорошо известны в России и за ее пределами. Продуманная система и тщательный подбор учебного материала, делали пособия Наливкина незаменимым руководством для лиц, изучавших узбекский язык. До их появления, как отмечал его ученик, впоследствии - выдающийся лингвист и этнограф Средней Азии М.С.Андреев, изучение языков коренного населения было трудным, почти невозможным. [19, с.34-35].

К числу выдающихся выпускников учительской семинарии, учеников Н.П.Остроумова и В.П.Наливкина принадлежали блестящие лингвисты, историки, этнографы с мировой известностью, такие как М.С.Андреев, В.Л.Вяткин, П.Е.Кузнецов, П.П.Иванов и другие, положившие начало целым научным направлениям. Все они являлись представителями туркестанского провинциального ориентализма и внесли свой вклад в практическое и научное изучение узбекского и других восточных языков, в становление лингвистической науки в Средней Азии.

Михаил Степанович Андреев - выдающийся русский лингвист, иранист, тюрколог, тончайший, глубокий знаток быта и вообще жизни Востока в Средней Азии и Индии, создатель среднеазиатской этнографической школы, первый директор Туркестанского Восточного института, заложивший основы высшего образования в крае. На формирование научных интересов Михаила Степановича Андреева большое влияние оказал его наставник и ангел хранитель Владимир Петрович Наливкин. Уже на склоне лет М.С.Андреев писал: «Я оставил гимназию и перешел в местную учительскую семинарию, где не только тогда преподавались местные языки: (персидский и узбекский, отчасти, одно время, арабский), но где был такой прекрасный преподаватель, как известный знаток языков и быта Средней Азии покойный В. П. Наливкин..., который удивительно умел без всяких выговоров и наказаний заставить учиться».[19]. Вероятно, именно под его влиянием у молодого Андреева сформировались представления о том, что занятия этнографией требуют безукоризненного знания языков, так же как для глубокого познания языка необходимо изучение быта, обычаев и фольклора. Этому принципу Михаил Степанович следовал в своей научной деятельности всю жизнь. М.С.Андреев был прекрасным знатоком узбекского языка, его бухарско - ташкентского диалектов, таджикского языка; реликтовых языков - язгулемского, шугнанского, ягнобского, ишкашимского, ваханского, многочисленных наречий и говоров, главным образом иранского корня, поражавшим маститых ученых тонкостью лингвистического слуха. П.Е.Кузнецов - стал в будущем известным тюркологом, преподавал на восточном факультете САГУ. В.Л.Вяткин стал известным археологом, этнографом Узбекистана, ученым с мировым именем.

Василий Лаврентьевич Вяткин - один из лучших учеников Н. П.Остроумова и В.П.Наливкина, востоковед, редкостный специалист по археологии Самарканда, сделавший выдающееся открытие XX века - нашедший и раскопавший обсерваторию Улугбека, видный знаток и собиратель рукописной книги, среди которых находились редчайшие, неизвестные науке сочинения. Ратовал за создание в Туркестане «центра изучения мусульманской культуры», спасение от расхищения иностранцами археологических эпиграфических и рукописных сокровищ края. Являясь специалистом в области узбекского и персидского языкознания, В.Л.Вяткин преподавал узбекский язык на вечерних курсах в Самарканде. В 1896 году В.П.Наливкины переехали в Самарканд. Научно - краеведческие интересы тесно сблизили его с деятельностью Самаркандского областного статистического комитета, среди членов которого был и его бывший ученик В.Л.Вяткин. Под руководством В.П.Наливкина в Самарканде был организован кружок народных чтений, в котором сотрудничали В.Л.Вяткин, Ю.О.Якубовский / отец известного востоковеда А.Ю.Якубовского/. Кроме того, не угас интерес В.П.Наливкина в этот период и к археологии. С новой силой он проявился в Самарканде. Несмотря на то, что 
данный вопрос не имеет прямого отношения к теме нашего исследования, однако хотелось бы отметить еще одну заслугу Владимира Петровича - его роль в обнаружении обсерватории Улугбека. Выше нами отмечалось, что заслуга обнаружения столь грандиозной и уникальнейшей находки принадлежала его ученику В.Л.Вяткину. Однако, в фонде Туркестанского кружка любителей археологии еще в 1990 году автором этой статьи была найдена квитанция телеграммы, отправленной 18 декабря 1898 года В.П.Наливкину Н.П.Остроумовым. На квитанции карандашом был написан текст телеграммы: «Напишите, где помещалась обсерватория Улугбека. Прибавьте местные предания. Остроумов». [20, л.30]. Известный историограф Узбекистана Б.В.Лунин в своей работе отмечал, что точное место обсерватории Улугбека было указано В.П.Наливкиным ещё в 1898 году, а именно, на заседании Туркестанского кружка любителей археологии 11 декабря 1898 года. [21.282]. Присутствовавший на этом заседании астрофизик Ташкентской обсерватории В.В.Стратонов сообщил, что В.П.Наливкин, основываясь на данных местных жителей и собственных раскопках, установил, что обсерватория находилась за арыком Снаб, неподалёку от арыка Оби - Рахмат у подножия холма.

Сохранились и неопубликованные работы В.П.Наливкина лингвистического цикла: «Список слов, заимствованных русскими из арабского, персидского и тюркского», «Туземные слова, сделавшиеся общеизвестными и вошедшие в употребление между русскими», «Русские слова, вошедшие в употребление у сартов», «Следы родства между арийцами и семитами». Первые три небольших словаря датированы октябрём 1892 года. Наличие данных рукописей свидетельствует о больших научных замыслах В.П.Наливкина в области лингвистических исследований. Особое место в числе неопубликованных работ по лингвистике занимал «Русско-узбекский словарь». Составленный первоначально вчерне между 1888 и 1891 гг. этот словарь был предметом пристального внимания автора. Он уточнял и перерабатывал его почти до самой смерти. ${ }^{1}$ В словаре около 18 тысяч слов. Это было детище всей его жизни и творческой работы. Законченный, но неопубликованный при жизни автора полный словарь узбекского языка, впоследствии был использован как один из источников при составлении многотомного узбекско-русского словаря.

Подводя итог можно сделать общий вывод о том, что русские исследователи-ориенталисты в Туркестане в конце XIX - начале XX вв. проделали огромную работу. От эмпирического накопления лингвистических данных (изучение живых языков, создание словарей, хрестоматий и пособий по узбекскому языку, и другим восточным языкам) их систематизации и обобщения, до создания в будущем крупных языковедческих трудов, заложивших основу узбекской лингвистики в современном понимании этого слова. Имена Владимира Петровича Наливкина и его жены Марии Владимировны Наливкиной вошли в биобиблиографический словарь тюркологов, что, несомненно, является высокой оценкой их трудов [22, с.170].

И сегодня труды Владимира Петровича Наливкина представляют собой огромное поле деятельности для историков, этнографов, географов, лингвистов, литературоведов... Они еще терпеливо ждут своих будущих молодых исследователей. Ровно 100 лет назад, 20 января 1918 года трагически оборвалась жизнь замечательного ученого и человека, с удивительной силой воплотившего в себе лучшие качества образованных русских людей Туркестанского края, который всей своей жизнью и творчеством заслужил уважение людей, среди которых он обрел свою вторую Родину.

\section{Список литературы:}

1.Ожегов С.И. Словарь русского языка. - М.: Русский язык. 1991. 915 с.

2.Боровков А.К. Узбекское языковедение. - Ташкент. 1942. 124 с.

3.Якубовский Ю.О. В.П.Наливкин // Туркестанский сборник. -Ташкент. Том 435.

4. Наливкин В.П., Наливкина М.В. Русско-сартовский и сартовско-русский словарь общеупотребительных слов, с приложением краткой грамматики по наречиям Наманганского уезда. - Казань. 1884. 355 с.

5.Наливкин В.П., Наливкина М.В. Грамматика сартского языка Андижанского наречия. - Казань. 1884.20 c.

6. Кононов А.Н. История изучения тюркских языков в России. Дооктябрьский период. - Ленинград: Наука. 1972. $272 \mathrm{c}$.

7.Кононов А.Н. Тюркское языкознание в Ленинграде. 1917-1967 // Тюркологический сборник. 1970. - М.: Наука, 1970. С.5-28.

8. Боровков А.К. Узбекское языковедение. - Ташкент. 1942. 243 с.

9.ЦГА Республики Узбекистан. Ф. И-47. Оп. 1. Д. 3027.

10.ЦГА Республики Узбекистан. Ф. И-47. Оп. 1. Д. 239.

11.Бендриков К.Е. Очерки по истории народного образования в Туркестане. (1865-1924). - М.: Академия педагогических наук. 1960. 612 с.

${ }^{1}$ Черновой вариант «Русско-узбекского словаря» находился в рукописном фонде библиотеки Института Востоковедения Академии наук Узбекистана, куда он был передан внучкой В.П.Наливкина. В государственной публичной библиотеке им. Алишера Навои в отделе редких книг и рукописей находился второй экземпляр этого словаря. 
12.Наливкин В.П. Сартовская хрестоматия для туркестанской учительской семинарии. - Ташкент. 1896. 96 c. / на узбекском языке/

13.ЦГА Республики Узбекистан. Ф. И-47. Оп.1. Д. 3027.

14. Лыкошин Н.С. Знание туземных языков. Сборник материалов по вопросу изучения туземных языков служащими по военно-народному управлению Туркестанского края. -Ташкент. 1905. 72 с.

15.Лунин Б. В. Историография общественных наук в Узбекистане. Биобиблиографические очерки. Ташкент: изд. Фан. 1974. 384 с.

16.Наливкин В.П. Азбука для русско-мусульманских школ оседлого населения Туркестанского края. Ташкент. 1886. 39 с.

17.Отчет Туркестанской учительской семинарии за 25 лет ее существования (30 августа 1879 г. - 30 августа 1904 г.) - Ташкент. 1904. 206 с.

18. Архив Ленинградского отделения Академии наук СССР (ныне - Российской Федерации) Ф. 87. Оп. 3. д. 272.

19. Цитируется по: Акрамова Х.Ф., Акрамов Н.М. Востоковед Михаил Степанович Андреев. - Душанбе: Ирфон. 1973. 223 с.

20.ЦГА Республики Узбекистан. Ф. И-71. Оп. 1. д.8.

21.Лунин Б.В. Из истории русского востоковедения и археологии в Туркестане. Туркестанский кружок любителей археологии. 1895-1917. - Ташкент: АН Уз.ССР. 1958. 320 с.

22. Биобиблиографический словарь отечественных тюркологов. Дооктябрьский период. - Москва.: Наука. 1989. $300 \mathrm{c}$.

\section{References}

1. Ozhegov S.I. Slovar' russkogo yazyka. - M.: Russkiy yazyk. 1991. 915 p.

2. Borovkov A.K. Uzbekskoye yazykovedeniye. - Tashkent. 1942. 124 p.

3. Yakubovsky Yu.O. V. P. Nalivkin // Turkestanskiy sbornik. -Tashkent. Vol. 435.

4. Nalivkin V.P., Nalivkina M.V. Russko-sartovskiy i sartovsko-russkiy slovar' obshcheupotrebitel'nykh slov, s prilozheniyem kratkoy grammatiki po narechiyam Namanganskogo uyezda. - Kazan'. 1884. 355 p.

5. Nalivkin V.P., Nalivkina M.V. Grammatika sartskogo yazyka Andizhanskogo narechiya. - Kazan'. 1884. 20 p.

6. Kononov A.N. Istoriya izucheniya tyurkskikh yazykov v Rossii. Dooktyabr'skiy period. - Leningrad: Nauka. 1972. $272 \mathrm{p}$.

7. Kononov A.N. Turkic linguistics in Leningrad. 1917-1967// Tyurkologicheskiy sbornik. 1970. - M.: Nauka, 1970. PP.5-28.

8. Borovkov A.K. Uzbekskoye yazykovedeniye. - Tashkent. 1942. 243 p.

9. Central State Administration of the Republic of Uzbekistan. F. I-47. Op. 1.D. 3027.

10. Central State Administration of the Republic of Uzbekistan. F. I-47. Op. 1.D. 239.

11. Bendrikov K.Ye. Ocherki po istorii narodnogo obrazovaniya v Turkestane. (1865-1924). - M.: Akademiya pedagogicheskikh nauk. 1960.612 p.

12. Nalivkin V.P. Sartovskaya khrestomatiya dlya turkestanskoy uchitel'skoy seminarii. - Tashkent. 1896. 96 p. / na uzbekskom yazyke /

13. Central State Administration of the Republic of Uzbekistan. F. I-47. Op. 1. D. 3027.

14. Lykoshin N.S. Znaniye tuzemnykh yazykov. Sbornik materialov po voprosu izucheniya tuzemnykh yazykov sluzhashchimi po voyenno-narodnomu upravleniyu Turkestanskogo kraya. -Tashkent. 1905. 72 p.

15. Lunin B. V. Istoriografiya obshchestvennykh nauk v Uzbekistane. Biobibliograficheskiye ocherki. - Tashkent: ed. Fan. 1974. 384 p.

16. Nalivkin V.P. Azbuka dlya russko-musul'manskikh shkol osedlogo naseleniya Turkestanskogo kraya. Tashkent. 1886. 39 p.

17. Otchet Turkestanskoy uchitel'skoy seminarii za 25 let yeye sushchestvovaniya (August 30, 1879 - August 30, 1904) - Tashkent. 1904. 206 p.

18. Arkhiv Leningradskogo otdeleniya Akademii nauk SSSR (nyne - Rossiyskoy Federatsii) F. 87. Op. 3. d. 272.

19. Tsitiruyetsya po: Akramova KH.F., Akramov N.M. Vostokoved Mikhail Stepanovich Andreyev. - Dushanbe: Irfon. 1973. 223 p.

20. Central State Administration of the Republic of Uzbekistan. F. I-71. Op. 1, file 8.

21. Lunin B.V. Iz istorii russkogo vostokovedeniya i arkheologii v Turkestane. Turkestanskiy kruzhok lyubiteley arkheologii. 1895-1917. - Tashkent: AN Uz.SSR. 1958. 320 p.

22. Biobibliograficheskiy slovar' otechestvennykh tyurkologov. Dooktyabr'skiy period. - Moskva.: Nauka. 1989. $300 \mathrm{p}$. 